\title{
Note on Sources and Terminology
}

Over the years, Japan-based scholars of emigration and ethnic studies, as well as those Japanese Americanists in the United States with expert reading knowledge of Japanese, have led the effort to excavate and compile Japanese-language sources that demonstrate the complexity and multiplicity inherent in Japanese American history. The decade of transnational research that culminated in this book contributes to this collective project of developing a growing body of primary sources in Japan and the United States that illuminate the variety of Nisei experiences on both sides of the Pacific. Among these sources are consular documents, intra-agency reports, and various other government records from the I920s to the I940s at the Diplomatic Archives of the Ministry of Foreign Affairs of Japan (formerly, the Diplomatic Record Office). These documents provide critical information about the Japanese government's perspectives on matters related to U.S.-born Nisei in Japan, their role in Japan's cosmopolitan empire, and the impact of their presence on U.S.-Japan diplomatic relations. In addition, many sporadic sources in Japan examined in this book offer valuable insights into the heavily understudied perspectives of Nisei migrants in the former Japanese Empire. They include material from the Japanese Overseas Migration Museum in Yokohama, the Kajiki Folklore Museum in Kagoshima Prefecture, and the Hiroshima Peace Memorial Museum.

In the United States a variety of archival sources related to Japanese American community organizations, immigration files, legal cases, and wartime records reveal the critical role that Nisei migrants and U.S.-born 
Kibei played in shaping the politics and culture of the Japanese American community and U.S. policies on citizenship, naturalization, and the World War II incarceration. The Japanese American Research Project (Yuji Ichioka) Collection at the University of California, Los Angeles, was a major source of prewar and wartime documents in both Japanese and English for this book. The U.S. government documents examined in this book include the records of the Immigration and Naturalization Service, the War Relocation Authority (WRA), the Commission on Wartime Relocation and Internment of Civilians (CWRIC), the Department of the War, and the Department of State at the National Archives and Record Administration and the Claremont Colleges Special Collections. Also examined in this book are primary source documents at the Bancroft Library at the University of California, Berkeley, which illuminate the early-twentiethcentury white nationalist campaign to exclude Nisei citizens in the American West.

Another critical aspect of my research involved tracing individuals in both countries to interview them and situate their experiences within Japanese and U.S. social, political, and cultural contexts from the early decades of the twentieth century to the post-World War II decades. I also used published memoirs, autobiographies, and a number of oral history collections in both countries, such as the Hibaku Taikenki (Atomic Bomb Memoir) Collection at the Hiroshima National Peace Memorial Hall for the Atomic Bomb Victims, the Nippon Hoso Kyokai (Japan Broadcasting Corporation) Senso Shogen (Wartime Testimony) Series, and the Japanese American National Museum's REgeneration Oral History Project. I also have examined many newspapers and magazines published in both countries from the I9Ios to the I980s. Thanks to the Hoover Institution's Hoji Shinbun Digital Collection, I was able to access a number of Japaneselanguage ethnic newspapers published in the United States during the first half of the twentieth century; these offered glimpses of Kibei's lives and perspectives often missing in the narratives of Japanese American history.

I follow the practice common among historians of Japanese America in using the terms Issei (first-generation Japanese immigrant), Nisei (secondgeneration Japanese American), and Kibei (Japanese American returnee from Japan) as both singular and plural. The names of Japanese individuals in Japan are listed as family names followed by given names, as is customary in Japan. The names of U.S.-born Japanese Americans and Japanese 
immigrants in the United States are written with given names followed by family names. Thus, at the risk of confusing some readers unfamiliar with how Japanese names are transliterated in different contexts, I have decided to render people's names the way that each individual used them at the time. All translations of Japanese-language sources are mine unless otherwise noted. 
This page intentionally left blank 
Citizens, Immigrants, and the Stateless 
This page intentionally left blank 